\title{
THE IMPLEMENTATION OF COLLABORATIVE LEARNING APPROACH THROUGH LITERACY TREE AND DICE ROLLING METHODS TO ENHANCE STUDENTS' LITERACY COMPETENCE AT MIN I KOTA TASIKMALAYA
}

\author{
HE N I P U R W I TR I \\ MIN 1 Kota Tasikmalaya, Kankemenag Kota Tasikmalaya, Jl. Sumelap raya Kota Tasikmalaya. \\ Email: henipurwitri@gmail.com
}

\begin{abstract}
This study aims at improving students' literacy competence by implementing collaborative learning approach through literacy tree and dice rolling methods, which are expected to promote discipline, responsibility, hard work and teamwork among students. This research unravels problems among students with lower reading skill in understanding reading concept and composing interrogative sentences in the reading text. The method used in this classroom action research (CAR) is qualitative-descriptive by which the author conducted two learning cycles. The result showed a significant improvement of students' literacy skills, for the average score in the first cycle was 54,93 compared to 82,03 in the second cycle. Thus, this method proved to be effective in improving students' reading comprehension, having a better learning experience and gaining a better learning outcomes of literacy competences.
\end{abstract}

KEY WoRDS: literacy competence, collaborative learning, classroom action research

\section{IMPLEMENTASI MODEL COLLABORATIVE LEARNING DENGAN MEDIA POHON LITERASI DAN METODE LEMPAR DADU BAGI PENGUATAN KEMAMPUAN LITERASI PESERTA DIDIK DI MIN 1 KOTA TASIKMALAYA}

\begin{abstract}
Abstrak
Penelitian ini bertujuan untuk meningkatkan kemampuan literasi peserta didik dengan membuat program pohon literasi kelas dengan media dadu dan model kolaboratif dalam menumbuhkan sikap disiplin, bertanggungjawab, kerja keras, dan kerjasama. Penelitian ini dilandasi oleh adanya permasalahan yaitu begitu minimnya pemahaman siswa dalam suatu bacaan serta pada materi membuat kalimat tanya dalam konsep bacaan. Metode yang digunakan peneliti adalah penelitian tindakan kelas (PTK) dengan kualitatif deskriptif yaitu memberikan soal yang berkaitan dengan cerita melalui dua siklus pembelajaran. Dari penelitian yang dilakukan diperoleh hasil bahwa pemahaman siswa semakin meningkat dengan rata-rata nilai siklus pertama yaitu 54,93 dan peningkatan signifikan terjadi pada rata-rata nilai siklus kedua yaitu 82,03. Dari data yang diperoleh tersebut dapat dilihat adanya peningkatan hasil belajar dari dua siklus. Dengan demikian model pembelajaran yang digunakan dalam materi tematik sangat bermanfaat untuk meningkatkan kemampuan literasi dan pemahaman siswa agar proses pembelajaran menjadi lebih baik lagi.
\end{abstract}

KatA KUnCI: Kompetensi literasi, pembelajaran kolaboratif, penelitian tindakan kelas

* Naskah diterima Februari 2020, direvisi April 2020, dan disetujui untuk diterbitkan Mei 2020 


\section{A. Pendahuluan}

Dalam Undang-Undang No. 20 Tahun 2003 tentang Sistem Pendidikan Nasional disebutkan bahwa "Pendidikan nasional berfungsi mengembangkan kemampuan dan membentuk watak serta peradaban bangsa yang bermartabat dalam rangka mencerdaskan kehidupan bangsa, serta bertujuan untuk mengembangkan potensi peserta didik agar menjadi manusia yang beriman dan bertakwa kepada Tuhan Yang Maha Esa, berakhlak mulia, sehat, berilmu, cakap, kreatif, mandiri, dan menjadi warga negara yang demokratis serta bertanggung jawab."

Untuk mewujudkan tujuan pendidikan nasional tersebut maka segenap upaya dilakukan oleh para pendidik dari berbagai tingkat pendidikan mulai dari jenjang pendidikan dasar hingga perguruan tinggi.

Salah satu upaya yang dapat dilakukan adalah dengan meningkatkan kemampuan literasi peserta didik. Untuk meningkatkan kemampuan literasi peserta didik adalah dengan menerapkan model pembelajaran yang bermutu. Melalui model pembelajaran yang bermutu, maka kemampuan literasi peserta didik akan semakin kuat dan berkembang. Hal ini menjadi landasan bagi peserta didik untuk memudahkan mereka dalam menyerap ilmu pengetahuan yang diajarkan oleh para guru di sekolah atau madrasah dan hal tersebut dapat dimulai dengan penguatan literasi di jenjang pendidikan dasar, yaitu sekolah dasar atau pun madrasah ibtidaiyah.

Dari hasil skor PISA 2018', Indonesia menempati posisi ke 72 dari 78 negara dengan skor 371, sedangkan rata-rata skor baca seluruh dunia adalah 487. Dibandingkan negara-negara lain di dunia, tingkat literasi anak-anak Indonesia masih sangat rendah, jauh tertinggal di bawah kemampuan negara ASEAN lainnya. Rendahnya literasi merupakan masalah mendasar yang memiliki dampak sangat luas bagi kemajuan bangsa. Kemampuan literasi yang rendah berkontribusi terhadap rendahnya produktivitas bangsa.

Untuk mengatasi masalah rendahnya tingkat literasi di Indonesia, maka upaya pengembangan literasi dapat dimulai di madrasah dari jenjang kelas kecil berlanjut ke kelas besar. Pembiasaan ini menjadi langkah terbaik untuk dapat meningkatkan kemampuan literasi anak-anak Indonesia mulai dari unit madrasah hingga dapat dikembangkan ke jenjang pendidikan selanjutnya.

Madrasah Ibtidaiyah Negeri 1 Kota Tasikmalaya memiliki misi untuk "Meningkatkan Kualitas Kegiatan Belajar Mengajar" maka sudah saatnya kita selaku pendidik membangun potensi peserta didik dengan segenap upaya yang ada dengan meningkatkan kinerja siswa melalui penguatan kemampuan literasi peserta didik.

Guru harus memahami bahwa upaya pengembangan literasi tidak berhenti ketika siswa dapat membaca dengan lancar dan memiliki minat baca yang baik sebagai hasil dari pembiasaan budaya literasi. Pengembangan literasi perlu terjadi pada pembelajaran di semua mata pelajaran untuk mengoptimalkan kemampuan berpikir tingkat tinggi. ${ }^{2}$

Dengan demikian perlu dilakukan penguatan kemampuan literasi peserta didik. Solusi yang dapat dilakukan adalah dengan menerapkan strategi pembelajaran yang menarik di kelas awal. Penguatan kemampuan literasi di kelas awal ini menjadi pondasi kemampuan lainnya yang pada akhirnya mampu mewujudkan pembelajaran yang lebih bermakna bagi peserta didik.

\section{Kajian Literatur \\ Berliterasi dengan media pohon literasi}

Gerakan Literasi Sekolah (GLS) tengah dilakukan pemerintah pada berbagai jenjang Pendidikan, terutama pada jenjang tingkat dasar SD/MI. Optimalisasi gerakan literasi pada jenjang SD perlu didukung dan dioptimalkan. Kegiatannya fokus pada penumbuhan dan pembiasaan membaca. ${ }^{3}$

Untuk mewujudkan pelaksanaan gerakan literasi agar membuahkan hasil yang memuaskan perlu didukung tersedianya fasilitas yang memadai dan berkesan bagi peserta didik.

Upaya yang dapat diterapkan pada jenjang kelas bawah adalah dengan membuat pohon literasi di kelas. Di samping dapat memperindah ruangan kelas, juga mampu mendorong peserta didik untuk selalu dekat dengan buku karena

${ }^{1}$ OECD. 2018. Survey International Program for International Student Assessment (PISA). (Online) (http://www.oecd.org/pisa).

${ }^{2}$ Joyo, Aceng. (2018). Gerakan Literasi Dalam Pembelajaran Bahasa Indonesia Berbasis Kearifan Lokal Menuju Siswa Berkarakter. Jurnal kajian Bahasa, Sastra dan Pengajaran (KIBASP). Volume 1, No. 2

${ }^{3}$ Apandi, Idris (2017). Penguatan Gerakan Literasi Pada Jenjang Sekolah Dasar. Tersedia. http :www.kompasiana.com, 16 Maret 2017 
termotivasi untuk selalu meningkatkan jumlah bacaan buku tiap harinya.

Untuk membuat pohon literasi ini pada dasarnya cukup mudah yaitu para peserta didik bersama guru membuat gambar pohon pada tembok kelas, kemudian membuat ranting dan daun-daunnya dengan kertas-kertas warna dimana pada kertas warna tersebut ditulis kalimat tanya yang sudah dibuat oleh masing-masing siswa dalam kelompok.

Disamping itu, guru perlu juga melakukan inovasi dalam menciptakan model pembelajaran yang diminati siswa agar senantiasa termotivasi untuk meningkatkan kemampuan literasinya. ${ }^{4}$

\section{Model Pembelajaran Collaborative Learning dengan Media Dadu dan Pohon Literasi}

Penerapan model pembelajaran collaborative learning pada dasarnya telah mengikuti pembiasaan membaca beberapa menit sebelum para siswa melaksanakan kegiatan belajar mengajar.

Peserta diberikan waktu selama 15 menit $^{5}$ untuk membaca buku sebelum pembelajaran dimulai, lalu membuat semacam resume yang isinya minimal memuat cerita apa yang telah dibaca, jumlah halaman, dan gambaran singkat materi yang dibaca. Setelah peserta membaca dan menempelkan hasil bacaan pada pohon literasi, perwakilan peserta ada yang tampil ke depan kelas dan menyampaikan secara lisan kepada para peserta yang lain tentang hasil bacaannya, dan memberikan kesempatan kepada peserta yang lain untuk menanggapinya. Untuk memodifikasi dan meningkatkan keaktifan siswa ini, maka dilakukanlah pembelajaran dengan media pohon literasi melalui metode lempar dadu dan collaborative learning.

Esensi dari collaboratibe learning adalah bekerja sama secara harmonis mencari solusi terhadap materi pembelajaran. Tujuan dari collaborative learning ini adalah mengembangkan kemampuan berpikir dan memecahkan permasalahan secara Bersama-sama.

Pembelajaran dengan media pohon literasi

\footnotetext{
${ }^{4}$ Kelana, Narwan Sastra (2019). Ajarkan Budaya Bacatulis.Tersedia :http://siedoo.com, 9 maret 2019

${ }^{5}$ Permendikbud No. 23 tahun 2015

${ }^{6}$ Maridi. (2009). Penerapan Model Collaborative Learning. Disampaikan dalam Seminar Lokakarya Nasional Pendidikan Biologi.FKIP UNS. 18 Juli 2009
}

melalui metode lempar dadu dan collaborative learning dimaksudkan untuk meningkatkan daya/ kemampuan baca peserta didik di MIN 1 Kota Tasikmalaya. Dengan meningkatnya kemampuan membaca peserta didik mendorong peningkatan prestasi akademik pula.

Variasi metode lempar dadu dan model pembelajaran collaborative learning yang digunakan membuat para peserta didik menjadi jauh lebih aktif, pembelajaran lebih menyenangkan, dan mampu memotivasi peserta didik dalam mengembangkan semangatnya selama proses kegiatan belajar mengajar. Setiap kegiatan dirasakan berbeda, berkesan serta menjadi lebih bermakna. ${ }^{7}$

Berikut adalah langkah-langkah yang dilakukan dalam proses pembelajaran tematik konsep "membuat kalimat tanya" dengan menggunakan media pohon literasi dengan model pembelajaran collaborative learning yang divariasikan dengan permainan lempar dadu.

1. Sebagai kegiatan awal, setiap anak dalam kelompok dibagikan sebuah teks cerita rakyat dengan berbagai judul.

2. Siswa diberi waktu 15 menit untuk menyelesaikan bacaannya.

3. Langkah selanjutnya, permainan diawali dengan guru membagikan dadu kepada setiap kelompok, dengan tiap nomor dadu berisi jenis pertanyaan yang berbeda. Jika dadu :

- Angka 1 : menyusun pertanyaan dengan kata "apa"

- Angka 2 : menyusun pertanyaan dengan kata "siapa"

- Angka 3 : menyusun pertanyaan dengan kata "di mana"

- Angka 4 : menyusun pertanyaan dengan kata "kapan"

- Angka 5 : menyusun pertanyaan dengan kata "mengapa"

- Angka 6 : menyusun pertanyaan dengan kata "bagaimana"

4. Setiap kelompok kemudian mencatat pertanyaan berupa kalimat tanya pada kertas berbentuk helaian daun beserta jawabannya.

5. Guru meminta siswa untuk membacakan tulisannya.

6. Guru berfungsi memperkuat jawaban yang

${ }^{7}$ Yadi (2019). Cara baru baca-tulis dengan Dadu dan Pohon Literasi. Tersedia :??belajarjuara1.com, 8 Juli 2019 
dikemukakan siswa.

7. Sebagai langkah terakhir, siswa memajangnya pada pohon literasi

Memahami Collaborative Leaning dan kaitannya dengan Penguatan Kompetensi Literasi.

Sejalan dengan implementasi kurikulum 2013, guru diharapkan dapat mengubah paradigma pembelajaran yang awalnya berpusat kepada guru (teacher centered) menjadi berpusat kepada siswa (student centered), melalui model pembelajaran kolaboratif (collaborative learning) mendorong para siswa memiliki pengalaman belajar yang bermakna, mampu berpikir kritis, kreatif,inovatif dan kemampuan literasi yang tinggi. ${ }^{8}$

Pembelajaran kolaboratif merupakan suatu model pembelajaran di mana siswa belajar dalam kelompok-kelompok kecil (umumnya terdiri dari 4-5 orang siswa) dengan keanggotaan yang heterogen (tingkat kemampuan, jenis kelamin, dan suku/ras berbeda) (Arends, 1998) ${ }^{9}$. Dalam menyelesaikan tugas kelompok, setiap anggota saling bekerja sama dan membantu untuk memahami suatu bahan pembelajaran.

Ide pembelajaran kolaboratif bermula dari perspektif filosofis terhadap konsep belajar. Untuk dapat belajar, seseorang harus memiliki pasangan. Pada tahun 1916, John Dewey, menulis sebuah buku "Democracy and Education" yang isinya bahwa kelas merupakan cermin masyarakat dan berfungsi sebagai laboratorium untuk belajar tentang kehidupan nyata. Melalui pembelajaran kolaboratif ini makan akan memudahkan peserta didik dalam kelompoknya untuk dapat saling berdiskusi satu sama lain dalam memahami konsep bacaan yang diberikan.

Peserta didik dalam kelompoknya diminta untuk memahami bacaan yang mereka baca. Secara berkolaborasi, mereka bermain dan menyusun sebuah kalimat berdasarkan angka dadu yang diperoleh. Peserta didik dituntut untuk meramu kalimat tanya dengan kalimat yang lengkap.

Dalam pembelajaran pengulangan terus berlangsung, peserta didik berulang kali membuat pertanyaan dan jawaban, serta mampu

${ }^{8}$ Apandi, Idris. (2018). Strategi Pembelajaran Aktif Abad 21 dan HOTS. Samudra Biru

${ }_{9}^{9}$ Arends, R.I. 1998. Learning to Teach. Singapore: McGrawHill Book Company. menemukan korelasi antara kalimat tanya dengan jawabannya. Sehingga mereka pada akhirnya mampu menyusun kalimat dengan kaidah penulisan kalimat yang lengkap berdasarkan struktur kalimat S (subjek) - P (predikat) - O (objek) - K (keterangan). Di samping itu, peserta didik mahir dalam menyusun kalimat tanya dengan menggunakan kata tanya pada awal kalimat dan tak lupa mengakhirinya dengan tanda tanya (?)

Dalam kelompoknya, peserta didik saling membantu satu sama lain dan pada akhirnya kemampuan memahami bacaan melalui kegiatan membuat kalimat tanya lengkap semakin mudah dilakukan oleh peserta didik.

Collaborative Learning memberikan kemudahan bagi peserta didik dalam mengembangkan komunikasi yang makin memperkuat kemampuan literasi peserta didik dalam kelompoknya. Kemampuan literasi tidak hanya terkait pada melek kemampuan membaca dan menulis saja. Namun, juga kemampuan berkomunikasi ketika pembelajaran tengah berlangsung.

Ketika murid bekerja dalam sebuah grup, mereka akan menjadi bagian dari suatu kelompok yang mana setiap anggota memberi bantuan atau dukungan satu sama lain. Kegiatan diskusi dan kolaborasi dalam pembelajaran ini tentunya sejalan pula dengan upaya menumbuhkan pendidikan karakter, yaitu untuk saling peduli satu sam lain.

Model collaborative learning membuat para siswa merasa nyaman dalam beraktivitas dalam sebuah kelompok belajar sehingga mereka dapat bekerja secara bersama-sama untuk saling menularkan pemahaman mereka. Collaborative learning juga memberi peluang bagi siswa untuk bertukar pikiran atau ide kepada rekannya. Manfaat collaborative learning yang lain adalah para siswa merasa diperhatikan, sebab mereka menemukan cara yang berbeda untuk bersosialisasi dan berinteraksi secara akrab dan penuh perhatian. Oleh karena itu, perangkat pembelajaran yang dikembangkan dapat meningkatkan karakter bersahabat siswa (Mustadi dan Wahyuni hal, 258. $)^{10}$

${ }^{10}$ Wahyuni Mei., Mustadi,Ali. Jurnal Pengembangan Perangkat Pembelajaran Collaborative Learning Berbasis Kearifan Lokal untuk Meningkatakan Kreatifdan Bersahabat. https://journal.uny.ac.id/index 


\section{B. Metode Penelitian}

Metode penelitian yang digunakan dalam penelitian ini adalah metode penelitian deskriptif kualitatif ${ }^{11}$ dalam bentuk PTK (penelitian tindakan kelas), yaitu prosedur penelitian yang menghasilkan data deskripsi berupa kata-kata tertulis atau lisan dari orang- orang dan perilaku yang dapat diamati. Penelitian Tindakan Kelas $(\text { PTK })^{12}$ ini berkaitan dalam kawasan bidang pendidikan yang dilaksanakan dalam kawasan sebuah kelas untuk memperbaiki dan meningkatkan kemampuan guru serta mengetahui pengaruh model pembelajaran yang diterapkan di kelas tersebut. Penelitian tindakan kelas ini diambil data deskriptif secara kualitatif dengan melukiskan objek penelitian berdasarkan fakta-fakta yang tampak atau sebagaimana adanya di dalam kelas objek.

PTK mempunyai karakteristik tersendiri yang membedakan dengan penelitian yang lain, di antaranya, yaitu: masalah yang diangkat adalah masalah yang dihadapi oleh guru di kelas dan adanya tindakan (aksi) tertentu untuk memperbaiki proses belajar mengajar.

Menurut Nawawi dan Martini ${ }^{13}$, penelitian deskriptif kualitatif berusaha mendeskripsikan seluruh gejala atau keadaan yang ada, yaitu keadaan gejala menurut apa adanya saat penelitian dilakukan.

Pengumpulan data dilakukan dengan pemberian soal pemahaman siswa pada bacaan pada siklus I dan siklus II, serta kuesioner yang berisi pertanyaan tentang pendapat atau opini siswa tentang model pembelajaran yang telah dilakukan. Kuesioner yang peneliti gunakan dalam penelitian ini adalah angket yang bersifat tertutup, karena jawaban yang harus dipilih sudah tersedia.

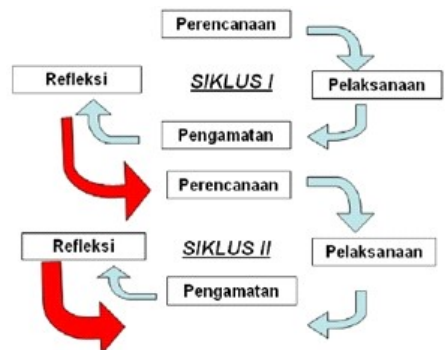

Tabel 1. Alur Penelitian Tindakan kelas

\footnotetext{
${ }^{11}$ Moleong, L.J. Metodologi Penelitian Kualitatif. Bandung: Remaja Rosdakarya, Cetakan Keenambelas , 2000

${ }^{12}$ Hadari Nawawi, H. Myrni Martini. Penelitian terapan (Yogyakarta : Gajah mada University Press, cet. 2, 1996)

${ }^{13}$ Hadari Nawawi, H. Myrni Martini. Penelitian terapan (Yogyakarta : Gajah mada University Press, cet. 2, 1996)
}

Penelitian Tindakan Kelas ini dilakukan dalam dua siklus, dimana setiap siklus terdiri dari empat tahap kegiatan yaitu (1) planning, (2) action, (3) observation, serta (4) reflection. Rancangan penelitian tindakan kelas merujuk pada Kemmis Mc. Taggart (dalam Arikunto, 2014:137) ${ }^{14}$.

Lokasi penelitian ini dilaksanakan di MIN 1 Kota Tasikmalaya kelas 2 Tahun Pelajaran 2019/ 2020 semester ganjil, dengan subjek peserta didik kelas II yang berjumlah 23 yang terdiri dari 13 lakilaki dan 10 perempuan. Indikator dalam penelitian ini adalah untuk mengkaji pengetahuan peserta didik dalam memahami materi tentang kalimat tanya $5 \mathrm{~W}+1 \mathrm{H}$ yang terdiri dari kata tanya what (apa), who (siapa), where ( dimana), when (kapan), dan how (bagaimana).

Instrumen yang digunakan dalam penelitian adalah silabus, rencana pelaksanaan pembelajaran, soal berupa 6 soal uraian dengan pertanyaan terbuka dengan mengacu jenis kata tanya $5 \mathrm{~W}+1 \mathrm{H}$, , dan kuesioner /angket. Sebelum digunakan sebagai instrumen penelitian, semua instrumen tersebut telah diverifikasi dan divalidasi oleh validator. ${ }^{15}$

Dalam siklus pembelajaran pertama, peserta didik hanya diberikan konsep penjelasan kata tanya dan membaca nyaring dengan cara yang biasa untuk selanjutnya peserta didik diuji dengan menjawab pertanyaan soal setelah menyimak bacaan cerita pendek yang diberikan oleh guru.

Setelah pembelajaran siklus I, selanjutnya guru melakukan penilaian (evaluasi) hasil pembelajaran pada siklus I untuk kemudian diperoleh nilai rata-rata siswa.

Guru selanjutnya melakukan refleksi berdasarkan hasil pengamatan dan evaluasi terhadap peserta didik pada siklus I.

Berdasarkan evaluasi pada siklus I, selanjutnya guru mempersiapkan kegiatan pembelajaran pada siklus II dengan model collaborative learning dan lempar dadu dengan media pohon literasi yang sudah ditempel di dinding kelas. Pembelajaran pada siklus ke II ini sebagai perbaikan pembelajaran yang telah dilakukan pada siklus I.

Dalam siklus ke II ini, peserta didik akan mempelajari kalimat tanya melalui proses

\footnotetext{
${ }^{14}$ Arikunto dan S. Jabar. Evaluasi Program Pendidikan. Jakarta: Bumi Aksara, 2010.

${ }^{15}$ Kepala Madrasah MIN 1 Kota Tasikmalaya
} 
pembelajaran yang menyenangkan melalui collaborative learning dan lempar dadu dengan durasi yang lebih lama. Meskipun pembelajaran berlangsung lebih lama namun proses pembelajaran menjadikan peserta didik jauh lebih paham dengan model yang menarik dan menyenangkan. Dalam proses pelaksanaannya, peserta didik akan membuat kumpulan kalimat tanya untuk selanjutnya ditempelkan di rantingranting pohon literasi. Di akhir pembelajaran, peserta didik diberikan soal yang sama dengan siklus I. Setelah itu, guru melakukan penilaian akhir siklus II.

Setelah 2 siklus pembelajaran dilakukan, guru selanjutnya membuat analisis hasil tes dan melakukan perbandingan rata-rata nilai antara hasil evaluasi siklus I dengan siklus II. Selama pembelajaran berlangsung, guru senantiasa mencatat dan memperhatikan setiap keterampilan dan sikap peserta didik dalam menjawab pertanyaan serta kemampuan mereka dalam menuangkan jawaban yang lengkap dari setiap pertanyaan yang diberikan.

\section{Hasil dan Pembahasan}

Pada penelitian ini dilakukan 2 kali siklus pembelajaran. Berikut hasil yang diperoleh dari 2 siklus pembelajaran yang telah dilakukan.

\section{Siklus I}

Siklus I dilakukan dalam 4 langkah yaitu perencanaan, tindakan, observasi dan refleksi.

Dari analisis evaluasi siklus I, sebagian besar siswa hanya menjawab pertanyaan sekenanya tanpa memperhatikan kaidah penulisan dalam menyusun kalimat lengkap yang terdiri atas Subjek (S)- Predikat (P)-Objek (O) dan Keterangan (K). $80 \%$ siswa hanya menjawab dengan jawaban singkat atau kalimat tidak lengkap.

Jawaban siswa dari setiap isian soal yang diberikan menunjukkan bahwa siswa masih mengalami kesulitan dalam menyusun sebuah kalimat lengkap dan masih kesulitan dalam mampu mendeskripsikan pemahamannya.

Untuk mengetahui lebih dalam kendala peserta didik, peneliti melakukan analisis tiap pertanyaan dan jawaban yang ada. Soal - soal yang diberikan berupa pertanyaan dengan menggunakan kata tanya yang berbeda-beda.

Berikut adalah grafik yang menggambarkan tingkat pemahaman siswa dalam berbagai jenis kata tanya $5 \mathrm{~W}+1 \mathrm{H}$ (apa, siapa, dimana, kapan, mengapa, dan bagaimana).

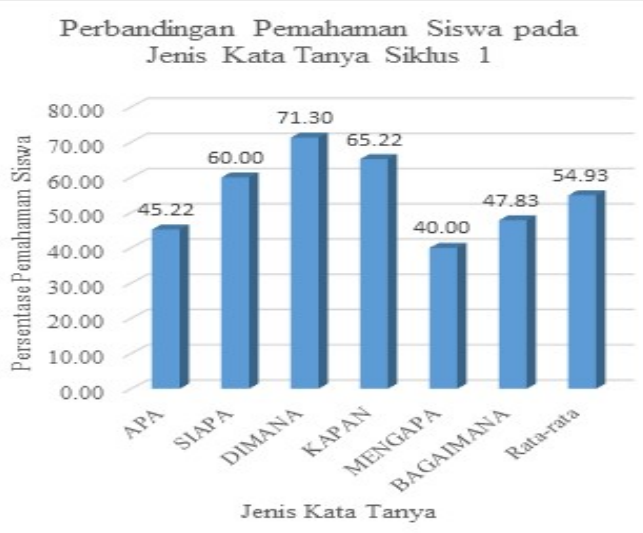

Gambar 1. Grafik Perbandingan Pemahaman Peserta Didik Pada Jenis Kata Tanya (Siklus 1)

Berdasarkan data grafik di atas dapat kita lihat bahwa pada pertanyaan dengan kalimat tanya "mengapa" memperoleh posisi paling rendah yaitu $40 \%$. Ini berarti peserta didik masih memiliki kesulitan dalam menguraikan alasan terhadap suatu permasalahan. Bahkan pada kata tanya "apa", peserta didik belum dapat menguraikan sebuah jawaban lengkap pada kolom yang tersedia. Sedangkan peserta didik jauh lebih memahami konsep pertanyaan "dimana" yang menanyakan tempat atau lokasi. Begitu pula, pada tingkatkan pemahaman kalimat tanya peserta didik pada kata tanya "siapa" $(60 \%)$, "kapan" $(65,22 \%)$ dan "bagaimana" $(47,83 \%)$ masih dirasakan sulit. Dari hasil yang diperoleh tersebuat maka didapatkah nilai rata-rata pemahaman peserta didik dalam konsep kalimat tanya pada siklus I yaitu $54,93 \%$.

Setelah diperoleh hasil, maka peneliti melakukan refleksi pembelajaran pada siklus I. Berdasarkan hasil analisis pembelajaran yang telah dilakukan pada siklus I, maka perlu adanya pembelajaran yang lebih menarik perhatian peserta didik serta dapat meningkatkan pemahaman mereka pada konsep bacaan dengan selalu dapat menjawab setiap pertanyaan dengan jawaban yang lengkap sesuai dengan kaidah penyusunan kalimat yang seharusnya. Di samping itu, peneliti melihat bahwa keterampilanketerampilan proses peserta didik masih dirasakan kurang sehingga pembelajaran belum dapat memberikan output yang memuaskan.

Seharusnya dalam setiap pembelajaran 
peserta didik diharapkan dapat menerapkan kemampuan berpikir ilmiah yang selaras dengan tujuan penguatan literasi, di antaranya mengidentifikasi pertanyaan ilmiah, memberikan penjelaskan fenomena secara ilmiah dan menggunakan bukti ilmiah yang sejalan dengan literasi sains ${ }^{16}$. Konsep pembelajaran literasi sains ini termaktub dalam pembelajaran tematik pada siswa kelas awal. Sehingga peserta didik kelas 2 dituntut pula untuk memiliki kemampuan literasi sains yang saling berhubungan dengan konsep dasar literasi berbahasa.

Menurut Diana et al. $(2015)^{17}$, agar kemampuan literasi dapat meningkat dengan baik, maka para pengajar dihimbau untuk mulai memperkenalkan dan membelajarkan materi dengan menggunakan berbagai strategi yang beraspek pada kemampuan literasi dan bukan hanya memperhatikan kemampuan pengetahuannya, antara lain membelajarkan materi melalui eksperimen yang dapat merangsang berpikir tingkat tinggi dan bersifat kontekstual. Selain menggunakan pembelajaran berdasarkan eksperimen kemampuan literasi dapat ditingkatkan dengan pembelajaran yang menekankan pada kemampuan menyelesaikan masalah (problem solving). Kemampuan menyelesaikan masalah ini dapat ditingkatkan melalui pembelajaran yang mampu mendorong peserta didik dalam menemukan solusi yang terkandung dalam collaborative learning ${ }^{18}$. Strategi lainnya yang dapat digunakan dalam pembelajaran dalam rangka peningkatan kemampuan literasi adalah dengan menggunakan media yang menarik dan memotivasi siswa. Dalam pembelajaran collaborative learning ini, media yang dapat mendorong keaktifan siswa itu adalah dadu dan pohon literasi.

Dalam informasi data statistika UNESCO, Indonesia menempati peringkat 60 dari total 61 negara $^{19}$. Artinya, tingkat literasi anak Indonesia

\footnotetext{
${ }^{16}$ Rustaman, Nuryani.2010. "Materi dan Pembelajaran IPA SD." Universitas Terbuka dalam Jurnal Zuriyano, Elsy. Literasi Sains dan Pendidikan.

${ }^{17}$ Diana, S., Arif, R. Euis, S. R. 2015. Profil Kemampuan Literasi Sains Siswa SMA berdasarkan instrument Scientific Literacy Assessments (SLA). Seminar Nasional xii Pendidikan Biologi FKIP UNS201

${ }^{18}$ Hastuti, Sri. 1996. Strategi Belajar Mengajar Bahasa Indonesia.. Jakarta : Departemen Pendidikan dan Kebudayaan Direktorat Jenderal Pendidikan Dasar dan Menengah. Bagian proyek Penataran Guru.

${ }^{19}$ Studi "Most Littered Nation In the World" . 2016. Central Connecticut State University.
}

rendah. Dari data tersebut, maka pemerintah tengah berupaya menggiatkan program literasi melalui berbagai media yang paling banyak diminati oleh siswa, yakni pohon literasi.

Pohon literasi terbentuk dari akar yang kokoh dan ranting-ranting yang dipenuhi dengan banyak helaian daun. Helaian daun itu berisi tentang bacaan peserta didik dalam berbagai bentuk kalimat. Jika semakin banyak murid membaca, maka akan banyak pula helaian daun yang memenuhi ranting-ranting pohonnya.

Dikarenakan pencapaian hasil pembelajaran di siklus I begitu rendah, peneliti kemudian melakukan kegiatan pembelajaran pada siklus ke II untuk dapat meningkatkan pemahaman siswa agar dapat meningkatkan kemampuan literasi peserta didik dengan strategi yang selaras dengan tujuan pendidikan nasional agar dapat meningkatkan peringkat Indonesia dalam statistika UNESCO.

Dalam siklus ke II , peserta didik melakukan pembelajaran materi tematik tentang kalimat tanya dengan terlebih dahulu memahami bacaan buku cerita melalui model collaborative learning lewat media dadu dan pohon literasi.

Dalam proses pembelajaran di siklus II, peserta didik terbagi dalam 5 kelompok, dimana masing-masing kelompok terdiri dari 4-5 orang. Selama proses pembelajaran siklus II berlangsung, seluruh siswa begitu aktif terlibat dengan antusiasme yang tinggi. Motivasi belajar mereka pun tampak lebih tinggi dibandingkan siklus I. Hal tersebut begitu tampak pada saat bergiliran membuat kalimat tanya berdasarkan angka dadu yang mereka peroleh serta ketika siswa berlombalomba untuk dapat menempelkan daun pada ranting-ranting yang tersedia.

Seperti pada pembelajaran pada siklus I, di siklus II peserta didik diberikan pertanyaan di akhir pembelajaran. Soal yang diberikan pun sama. Para peserta didik kembali mencoba untuk menjawab pertanyaan dengan tingkat pemahaman masing-masing dan berupaya untuk menjawab pertanyaan dengan kalimat lengkap sesuai dengan kaidah penulisan yang telah diajarkan. Selanjutnya dari jawaban peserta didik tersebut, peneliti akhirnya memperoleh data untuk mengevaluasi kegiatan pembelajaran yang telah berlangsung di siklus II.

Berikut hasil evaluasi yang diperoleh pada siklus II: 


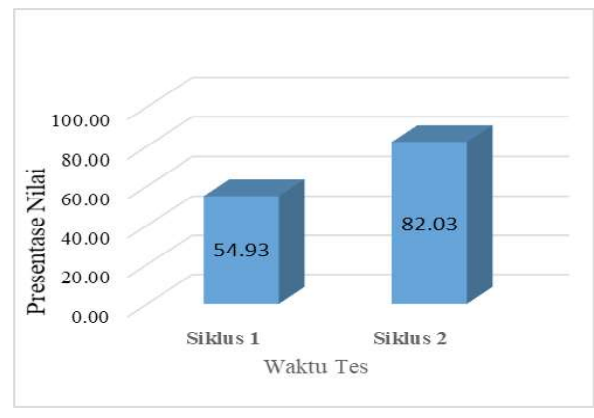

Gambar 2 . Grafik Perbandingan Pemahaman Peserta Didik Pada Jenis Kata Tanya (Siklus II)

Berdasarkan data pada grafik di atas, dapat kita peroleh nilai prosentase pemahaman siswa pada jenis kata tanya dari yang terbesar hingga terkecil yaitu kata tanya "siapa", "dimana", "kapan", dan bagaimana" memperoleh nilai yang sama yaitu $82,61 \%$, selanjutnya kata tanya "mengapa" $(81,74 \%)$ dan siapa $(80 \%)$. Dari keseluruhan nilai yang diperoleh, didapatkan ratarata pemahaman peserta didik konsep jenis kata tanya adalah $82,03 \%$.

Dalam siklus II, siswa menunjukkan peningkatan kemampuan kompetensi yang jauh lebih berkembang dibandingkan dengan siklus I. Indikator ini diperlihatkan dari kemampuan peserta didik dalam menyusun kalimat lengkap dengan baik. Hal ini menunjukkan bahwa peserta didik sudah jauh lebih memahami konsep bacaan yang diberikan dan mampu membuat rangkaian kalimat sesuai kaidah penulisan yang tepat.

Hal ini terbukti pula dengan perbedaan signifikan nilai rata-rata tes siklus I dan siklus II. sebagai berikut:

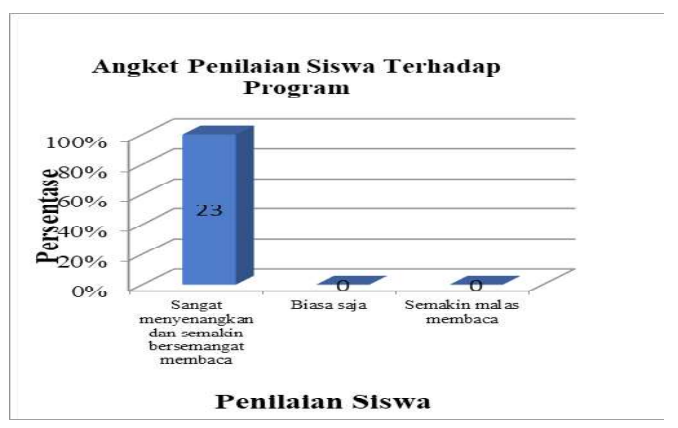

Gambar 3. Grafik Peningkatan Pemahaman Siswa

Pada awalnya prosentase nilai rata-rata peserta didik dalam memahami bacaan dan menjawab pertanyaan hanya 54,93. Namun setelah dilakukan treatment menggunakan model collaborative learning dengan media dadu dan pohon literasi diperoleh hasil yang meningkat yaitu 82,03 .

Setelah pembelajaran pada siklus II berakhir, peserta didik diminta pula untuk mengisi kuesioner yang disediakan oleh guru untuk mengetahui pendapat dan kesan peserta didik setelah diterapkannya pembelajaran literasi dengan model collaborative learning dan media dadu dan pohon literasi.

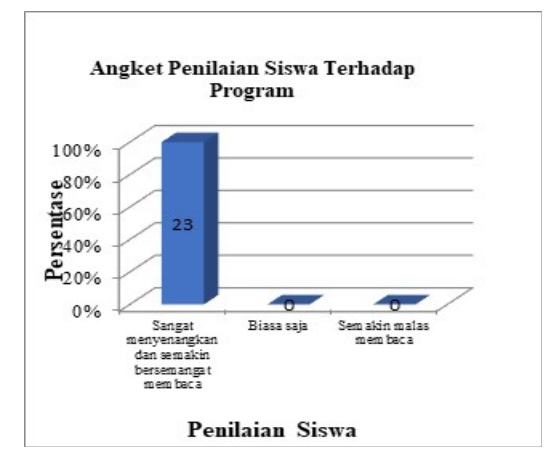

Gambar 4.Angket Penilaian Siswa Terhadap Program

Hasil dari kuesioner menunjukkan seluruh siswa, berjumlah 23 orang $(100 \%)$ menyatakan bahwa pembelajaran tematik dengan model collaborative learning dengan media dadu dan pohon literasi sangat menyenangkan dan mendorong siswa untuk semakin bersemangat dalam membaca. Dengan demikian model pembelajaran ini terbukti mampu menguatkan kemampuan literasi peserta didik yang terlihat dari adanya peningkatan daya baca mereka melalui peningkatan rata-rata nilai yang sangat signifikan.

Adanya peningkatan daya baca yang dimiliki oleh peserta didik tersebut dipengaruhi adanya strategi yang telah peneliti lakukan, di antaranya:

1) Penerapan model pembelajaran yang menyenangkan dan atraktif ${ }^{20}$;

2) Adanya kolaborasi dan peran aktif siswa dalam berbagi kebiasaan membaca;

3) Meningkatkan kepercayaan diri siswa dalam menjawab pertanyaan soal dan menguraikannya dalam bahasa tulisan;

\footnotetext{
${ }^{20}$ Prahara, Haris.2017. Dongkak Minat Baca anak dengan metode kreatif. Jakarta : Kompas
} 
4) Berkembangnya kemampuan berpikir analisis siswa setelah dilakukan pembelajaran berulang kali dari siklus I hingga siklus II.

\section{Kesimpulan}

Berdasarkan hasil penelitian dan analisis data yang diperoleh, maka dapat disimpulkan bahwa kemampuan literasi peserta didik kelas 2 MIN 1 Kota Tasikmalaya mengalami peningkatan yang signifikan setelah diterapkan model pembelajaran ini. Hal ini terbukti dari perubahan rata-rata nilai dengan range yang cukup tinggi saat dibandingkan antara nilai tes siklus I maupun siklus II. Pada saat siklus I, rata-rata nilai yang diperoleh oleh peserta didik hanyalah 54,93, namun siklus II diperoleh rata-rata nilai peserta didik yang mampu mencapai hingga 82,03.

Penulis telah mendapatkan sejumlah capaian di antaranya:

1. Mampu mengatasi permasalahan daya baca dan kemampuan menulis peserta didik dengan menggunakan media pohon literasi dan dadu melalui model collaborative learning.

2. Meningkatnya antusiasme dan semangat siswa dalam membaca dengan senantiasa menjawab pertanyaan dengan kalimat lengkap sesuai dengan kaidah penulisan pada pohon literasi serta semakin gemar membaca di ruang pojok baca di kelas.

Seluruh tahapan kegiatan penelitian tindakan kelas tersebut telah terlaksana dengan baik tentunya dengan partisipasi dan dukungan semua pihak yang ada di lingkungan MIN 1 Kota Tasikmalaya. Semoga tahapan kegiatan yang telah dilaksanakan dapat berkontribusi positif bagi terwujudnya visi dan misi serta penguatan nilainilai organisasi di MIN 1 Kota Tasikmalaya.[] 
Apandi, Idris, Baehaqi, Arip. 2018. Strategi Pembelajaran Aktif Abad 21 dan HOTS. Yogyakarta : Samudra Biru

Arikunto, S. Jabar. 2010. Evaluasi Program

Pendidikan. Jakarta: Bumi Aksara, 2010.

Arikunto, Suhardjono. 2015. Penelitian Tindakan Kelas. Jakarta : Bumi Aksara

Gokhalde, A Anuradha. 1995. Journal of Technologi Education: CollaboraionLearning Enhances Critical ThingkingVol 7 No.1

Khoirudin, A., Setyawati, R.D., \& Nursyahida, F. 2017. Profil Kemampuan Literasi Matematika Siswa Berkemampuan Matematis Rendah dalam Menyelesaikan Soal Berbentuk PISA. AKSIOMA. 8(2): 3342.

Lestari, E.I. Pentingnya Penerapan Collaborative Learning pada Pembelajaran SD dengan Tepat. Fakultas Ilmu Pendidikan, Universitas Negeri Yogyakarta

Maryanto, M. D. 2006. Quantum Seni. Semarang: Dahara Prize. National Research Council (NRC). 1996. National Science Education Standarts. Washington: National

Moleong, L.J. Metodologi Penelitian Kualitatif.Bandung: Remaja Rosdakarya, CetakanKeenambelas, 2000.

OECD. 2018. Survey International Program for International Student Assessment (PISA). (Online) (http://www.oecd.org/pisa).

Probosari, R. M., Sajidan, Suranto, \& Prayitno, B. A. 2016. Dampak Inkuiri Berjenjang terhadap Dimensi Literasi Sains Calon Guru Biologi. Proceeding Biology Education Conference.
Rizkita L., Suwono, H., \& Susilo. H. 2016. Analisis Kemampuan Awal Literasi Sains Siswa Sma Kota Malang. Seminar Nasional II Kerjasama Prodi Pendidikan Biologi FKIP dengan Pusat Studi Lingkungan dan Kependudukan (PSLK) Universitas Muhammadiyah Malang.

Wahyuni Mei., Mustadi,Ali. Jurnal Pengembangan Perangkat Pembelajaran Collaborative Learning Berbasis Kearifan Lokal untuk Meningkatkan Kreatif dan Bersahabat. https:// journal.uny.ac.id/index.php/jpka/article/ viewFile/12056/8601.

Winata, A., Cacik, S., \& Widyawati, I. S. R. 2017. Pengembangan Petunjuk Praktikum IPA Berbasis Literasi Sains untuk Calon Guru Sekolah Dasar. Seminar Nasional Hasil Penelitian dan Pengabdian kepada Masyarakat II 